Article

\title{
Evaluation of the Effectiveness of Pod Sealants in Increasing Pod Shattering Resistance in Oilseed Rape (Brassica napus L.)
}

\author{
Dainius Steponavičius ${ }^{1}$, Aurelija Kemzūraitè ${ }^{1, * \mathbb{D}}$, Laimis Bauša ${ }^{1}$ and Ernestas Zaleckas ${ }^{2}$ \\ 1 Institute of Agricultural Engineering and Safety, Vytautas Magnus University, Studentu St. 15A, \\ LT-53362 Akademija, Kaunas distr., Lithuania; Dainius.Steponavicius@vdu.lt (D.S.); \\ laimisbausa@gmail.com (L.B.) \\ 2 Institute of Environment, Vytautas Magnus University, Studentu St. 11, LT-53361 Akademija, Kaunas distr., \\ Lithuania; Ernestas.Zaleckas@vdu.lt \\ * Correspondence: Aurelija.Kemzuraite@vdu.lt
}

Received: 29 April 2019; Accepted: 11 June 2019; Published: 13 June 2019

check for updates

\begin{abstract}
Shattering of pods of oilseed rape (Brassica napus L.) is a major cause of seed yield losses prior to and during harvesting. In order to reduce shattering, researchers have been engaged in the development of special preparations that are known as pod sealants (PS). Despite the fact that there are already developed and commercialized PSs that have only been effective on seed yield preservation under certain environmental conditions, there is still a need to create a more versatile and efficient PS. Currently, the most promising method of controlling pod shattering in oilseed rape is the application of our developed novel acrylic- and trisiloxane-based pod sealant (PS4). The effectiveness of PS4 and three commercial pod sealants (PS1, PS2, and PS3) was assessed in this comparative study. By spraying an oilseed rape crop with PS4, natural seed loss can be reduced by $20-70 \%$, depending on the prevailing weather conditions, and loss of seeds during harvest can be reduced by more than three-fold compared with that by the control treatment. Thus, the overall results demonstrated that by applying a novel pod sealant (PS4) to oilseed rape crops 2 weeks before harvest can increase the net profit margin by $€ 30-€ 150 \mathrm{ha}^{-1}$. The life cycle assessment showed that during 2014-2016 oilseed rape cultivation, the largest effect on global warming emission $\left(\mathrm{kg} \mathrm{CO}_{2} \mathrm{eq}\right)$ reduction was experimental sealant PS4, i.e., approximately $17 \%$ compared to the control.
\end{abstract}

Keywords: winter oilseed rape; combine harvester reel; pod strength; life cycle assessment; seed loss

\section{Introduction}

Oilseed rape (OSR, Brassica napus L.) belongs to the Brassicaceae family, is a globally important oilseed crop that probably originated in the Mediterranean region, and is widely grown in temperate agricultural regions [1-3]. OSR ranks third amongst the global key sources of vegetable oil after soy and palm. It is widely used for industrial purposes (mainly for biodiesel production) $[1,4,5]$. Recently, its worldwide production reached approximately 70 million tons from approximately 34 million hectares, 22 million tons of which was produced from approximately 6.5 million ha in the European Union [6]. OSR has become a major commercial crop in Europe, where it is also considered to be important in crop rotation [7,8]. In Europe, winter OSR is more widely grown than spring OSR because winter OSR is 1.5-2 times more productive than spring OSR [9,10].

Unusually for major agricultural field crops, OSR tends to shed its seed as soon as the fruits become fully ripe, reflecting the primitive need for seed dissemination [11,12]. The botanical name of Brassicaceae fruits is siliques or agronomically, pods, which enclose the seeds during their development $[13,14]$. Siliques consist of two valves (i.e., the carpels or fruit walls) that form two 
locules separated by the replum. The site where the valve margin connects to the replum is called the dehiscence zone, a layer where cell separation occurs so that the silique could open [15]. The process of pod dehiscence, also known as pod shattering, which is accompanied in OSR by the degradation of the cell wall of the siliques.

One of the causes of cell wall degradation is the weakening of the valve attachment leading to pod shattering [16]. Pod shattering is caused by a build-up of tension in the pod due to lignification of cells surrounding the dehiscence zone in the final stage of pod development. OSR pod shattering can be reduced by lowering the tension occurring in the pod wall or by widening the dehiscence zone [17]. The process of dehiscence usually starts at the proximal end of the siliques [14]. In addition, physical pressure build up, as the silique dries, creates mechanical stresses that contribute to the pod shattering [11].

Pod shattering leads to major seed (and hence yield) total losses of $15-70 \%$, depending on the conditions. Pod shattering is also the main source of OSR soil seedbanks and volunteers in the subsequent crop $[18,19]$. Loss of seeds in OSR variates a lot and depends on the varieties and genotype [20-22]. Winter Brassica napus cultivars are more resistant to pod shattering than spring cultivars [23]. OSR loss of seeds is generally split into two periods: shattering prior to and at the time of harvesting. Preharvest OSR seed loss can reach up to $2.5 \%$ under favorable weather conditions [24], which may increase due to unfavorable weather conditions, such as strong winds [25], hail [26], and frequent changes in temperature and moisture [11]. Kosteckas et al. [27] reported that under adverse weather conditions, the loss of seed due to pod shattering could be $>400 \mathrm{~kg} \mathrm{ha}^{-1}$ or $>12 \%$. Preharvest seed losses are caused not only by pod shattering but also due to pod drop [28] and more synchronous maturation of the pods on the plant [29]. Gan et al. [30] observed that higher OSR plant populations and reduced branching of individual plants induce greater synchronicity in the maturation of OSR pods. Preharvest seed loss of OSR can be lowered by decreasing the maturation time [31]. Fully mature pods of OSR are very prone to splitting, resulting in pod shattering and seed loss [32].

Seed loss at harvesting of winter OSR usually is from 2 to $5 \%$ (under ideal conditions), and from 11 to $25 \%$ or higher (under adverse conditions) [24,33,34]. Yield losses of $20-25 \%$ have been reported in cases of delay in harvesting beyond the optimal time [26,34]. The two main methods of harvesting OSR are swathing (or windrowing) and direct harvest (direct combining). Nunes et al. [21] have corroborated their hypothesis that swathing reduces pod shattering when pods are harvested at the ideal time. During the direct harvest method, pod shattering occurs due to the application of external forces, such as contact with the combine harvester reel [35]. Use of appropriate harvest management strategies can minimize the impact of unfavorable weather conditions and the yield loss of OSR due to pod shattering [30]. OSR seed loss can be reduced using well-equipped (with extended cutter bar table and vertical double-knife active dividers) and adjusted combine harvester reels [35,36]. In addition, an inappropriate working speed of the combine harvester can be associated with seed loss at harvest [33]. Furthermore, use of plant growth regulators can decrease OSR seed losses at harvest [37].

Trials on the application of commercial pod sealants to OSR crops have generated variable results, particularly under field conditions $[21,23,27,36,38,39]$. Currently, the most promising method of controlling pod shattering in OSR is the application of a recently developed acrylic- and trisiloxane-based pod sealant, these substances work by physically preventing valve separation by gluing them together and altering the pod moisture regime. The sealant allows moisture to leave the pod but prevents from getting into it, thus decreasing pod expansion and contraction resulting from watering and drying cycles [38]. Previous studies have suggested that this acrylic- and trisiloxane-based pod sealant (PS4) is environmentally friendly, does not penetrate seeds in the treated pods, and does not reduce oil content [38]. However, no study has evaluated the influence of different weather conditions on OSR pods treated with this sealant in terms of their pod strength or moisture content and subsequent losses prior to and during harvesting. Moreover, the published studies have not evaluated the effectiveness 
of this sealant in terms of environment and economic benefit nor have they compared its effects with those of commercial sealants of different compositions.

In order to rate the sustainability of OSR production, all possible environmental factors that have an impact over the entire lifespan must be considered. This can be achieved by employing a Life Cycle Assessment (LCA). LCA is among the best and common methods for the evaluation environmental impacts of agricultural technologies and products [40]. This method also gives a possibility to identify opportunities for environmental improvement. LCA methodology can be used to evaluate the environmental load of OSR cultivation and products during their life cycle "from inception to the death" [41].

It is possible to conclude from the LCA analysis that was performed that the carbon footprint is affected by the OSR yield per hectare: the yield of the plot with the lowest environmental impact was the highest and, and on the contrary, the yield of the plot with the highest impact was the lowest [42]. In research of Forleo et al. [42] related to the Greenhouse gas (GHG) emissions of OSR cultivation, the carbon footprint was $768 \mathrm{~kg} \mathrm{CO}_{2} \mathrm{eq} \mathrm{Mg}^{-1}$ (or one ton), i.e., lower than emerged in some other studies. The authors stated that this could happen due to the differences between data, approaches, and the employed agricultural practices. While, in the study of Saarinen et al. [43], the determined carbon footprint of rapeseed cultivation was $1480 \mathrm{~kg} \mathrm{CO}_{2} \mathrm{eq} \mathrm{Mg}^{-1}$. Naujokienè et al. [44] in a Lithuanian study found that the carbon footprint for winter oilseed rape (WOSR) cultivation depends on soil biopreparation and varies in range from 682.00 to $1136.89 \mathrm{~kg} \mathrm{CO}_{2}$ eq $\mathrm{Mg}^{-1}$. It can be concluded from the LCA results that the global warming potential (GWP) for OSR production in Italian regions amounts to $1106 \mathrm{~kg} \mathrm{CO}_{2}$ eq $\mathrm{Mg}^{-1}$ in Sardinia [45] and to $1300 \mathrm{~kg} \mathrm{CO}_{2}$ eq $\mathrm{Mg}^{-1}$ of seed generated in the Campania [46]. Bieńkowski et al. [47] determined that the carbon footprint of OSR crops in Poland showed that on average it was $794.2 \mathrm{~kg} \mathrm{CO}_{2}$ eq $\mathrm{Mg}^{-1}$ of seed. Mousavi-Avval et al. [40] employed an LCA of OSR production and showed that the GWP was $1181.6 \mathrm{~kg} \mathrm{CO}_{2} \mathrm{eq} \mathrm{Mg}^{-1}$ of seed, of which $845 \mathrm{~kg} \mathrm{CO}_{2}$ eq was related to the emissions from farms. In addition, the acidification and eutrophication potentials were found to be $23.3 \mathrm{~kg} \mathrm{SO}_{2} \mathrm{eq} \mathrm{Mg}^{-1}$ and $18 \mathrm{~kg} \mathrm{PO}_{4} \mathrm{eq} \mathrm{Mg}^{-1}$, respectively. These authors have confirmed that fertilizers and their emissions from fields contribute more than $90 \%$ of GWP in OSR cultivation.

From the perspective of the environment and in relation to the GWP, the study of Forleo et al. [42] highlighted that rapeseed crop (carbon footprint $768 \mathrm{CO}_{2} \mathrm{eq} \mathrm{Mg}^{-1}$ ) is more sustainable than sunflower (895 $\mathrm{CO}_{2}$ eq $\mathrm{Mg}^{-1}$ ) crop cultivation. Rapeseed farms could generate higher yields and be way less environmentally damaging than the farms of sunflowers in Italy. Similar conclusions, that rapeseed profile is way better than that of sunflower, were made also in Chilean conditions [48] due to the following factors: there were less mineral fertilizers per unit of seeds produced, the application of less toxic herbicides, and use of no-tillage systems (which reduces both diesel consumption and equipment use in the field).

Research of Khanali et al. [49] shows values of impact categories per one ton of packaged OSR edible oil, from the farm to the end of the packaging stage. The authors reported that $3085.70 \mathrm{~kg} \mathrm{CO}$ eq are emitted to the atmosphere per production of one ton of packaged OSR edible oil. Emissions from the farm stage are much more than others and consist $78 \%$ (direct $1587.6 \mathrm{~kg} \mathrm{CO}_{2}$ eq and indirect $848.0 \mathrm{~kg} \mathrm{CO} 2$ eq) [49]. The total GWP ( $\mathrm{kg} \mathrm{CO}_{2}$ eq) is a crucial factor, in which variations can also be addressed for other GHG changes and dependencies [44].

LCA based evaluation of OSR shows that the difference in the carbon footprint of the farms is predominantly a result of the following factors: the different values of seed yield of OSR; the different levels of fuel consumption; and the differing amounts of nitrogen fertilizers used [42]. Previous experiments [50] confirmed the research results of Forleo et al. [42]. Both the choice of fertilizer type [51] and fertilization management [52] have significant implications in the environmental impacts. There is a large amount of published LCA studies of OSR cultivation, especially about feedstock for biofuels production. Many researchers used LCA to study environmental impacts in production of OSR $[40,44,49,52,53]$. A wide range of calculators have been developed to assess the GHG emissions of 
agricultural products [54]. Therefore, there is still a need to evaluate the environmental sustainability of OSR pod sealants.

The main objectives of this study were (i) to investigate the effects of this novel pod sealant (PS4) on seed and pod valve moisture during harvesting and on pod strength and shattering and (ii) to evaluate the environmental and commercial benefits (if any) of using different pod sealants.

The hypothesis states that the developed acrylic- and trisiloxane-based pod sealant reduces rapeseed losses and the adverse environmental impacts prior and during winter OSR harvesting.

\section{Materials and Methods}

\subsection{Pod Sealant Field Trials}

Studies were conducted in 2014, 2015, and 2016 at the Laboratory-Experimental Station for Investigation of the Technological Processes of Agricultural Machinery, Aleksandras Stulginskis University (currently Agriculture Academy of Vytautas Magnus University), Lithuania. Each year, a different area of 5 ha of the winter OSR variety Cultus was chosen for the trials. On 7 July 2014; 3 July 2015; and 28 June 2016, 2 weeks before harvesting the OSR crop, individual plots of OSR were sprayed using an Amazone UF 901 sprayer (Amazone GmbH, Hasbergen, Germany), which has a coverage of $12 \mathrm{~m}$. OSR plants were sprayed with one of four pod sealants containing different active substances: turpene polymer (PS1), carboxylated styrene butadiene copolymer with alkyl phenyl hydroxyethylene (PS2), turpentine resin (PS3), and an experimental polyether-polysiloxane copolymer with a styrol-acrylate copolymer-based sealant (PS4). The chemical compositions of the pod sealants were based on di-1-p-menthene $\left(555.4 \mathrm{~g} \mathrm{~L}^{-1}\right)$ and alcohol ethoxylate $\left(90.0 \mathrm{~g} \mathrm{~L}^{-1}\right)$ for PS1 (commercial product); carboxylated styrene butadiene copolymer $\left(450.0 \mathrm{~g} \mathrm{~L}^{-1}\right)$ and aliphatic oxyalkylated alcohol (100.0 $\left.\mathrm{g} \mathrm{L}^{-1}\right)$ for PS2 (commercial product); and pine resin $\left(960 \mathrm{~g} \mathrm{~L}^{-1}\right)$ and nonaethylene glycol $\left(25 \mathrm{~g} \mathrm{~L}^{-1}\right)$ for PS3 (commercial product). PS4 was produced in a laboratory reactor by homogenizing polyalkyleneoxide-modified heptamethyltrisiloxane $\left(250 \mathrm{~g} \mathrm{~L}^{-1}\right)$ with an acrylic dispersion $\left(350 \mathrm{~g} \mathrm{~L}^{-1}\right)$ by adding polyethylene glycol $\left(200 \mathrm{~g} \mathrm{~L}^{-1}\right)$ and water (rest) [38]. The dosages applied to the field trials were $1.25 \mathrm{~L} \mathrm{ha}^{-1}$ (6.25 g kg-1 concentration) PS1, $1.0 \mathrm{~L} \mathrm{ha}^{-1}\left(5.00 \mathrm{~g} \mathrm{~kg}^{-1}\right)$ PS2, $1.3 \mathrm{~L} \mathrm{ha}^{-1}\left(6.50 \mathrm{~g} \mathrm{~kg}^{-1}\right)$ PS3, and $0.4 \mathrm{~L} \mathrm{ha}^{-1}\left(2.00 \mathrm{~g} \mathrm{~kg}^{-1}\right)$ PS4, with each sealant sprayed on two lines (12-m width) of the field (Figure 1).

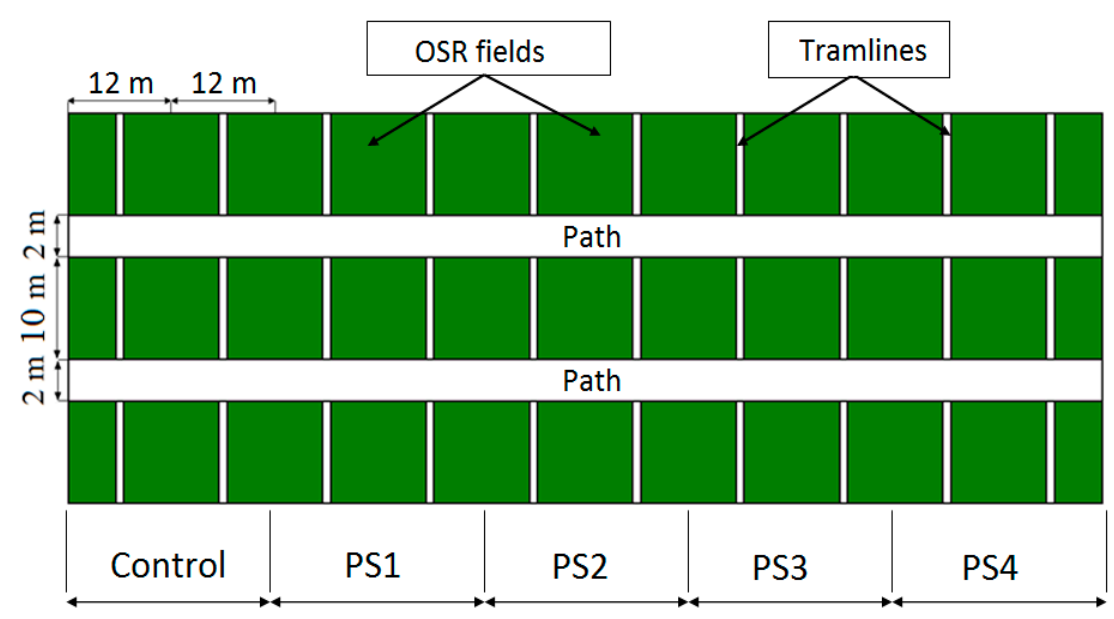

Figure 1. Research field trial scheme.

Prior to the study, an area of $4080 \mathrm{~m}^{2}$ was selected from the original area of $5 \mathrm{ha}$. It was divided into five different plots, four of which were sprayed with one of the pod sealants and one control field was sprayed with water without sealant. 


\subsection{Weather Conditions}

The meteorological parameters during July-August 2014-2016 were collected at the Kaunas Meteorological Station of the Lithuanian Hydrometeorological Service, located approximately $0.5 \mathrm{~km}$ from the trial plots.

\subsection{Laboratory Measurements of Pod Strength}

There are several laboratory methods of determining pod strength: tensile strength test [29], the cantilever test [55], pendulum test [56,57], random impact test (RIT) [58], and the variable-speed pod splitter [59]. The pod stem-bending method, i.e., quasi-static bending of the silique beak [60], was performed for determining pod strength using a Digital Texture Analyser (TA.XT Plus, Stable Micro Systems Ltd., Godalming, Surrey, UK). Pod strength was measured each year on the day of OSR harvest (23 July 2014; 27 July 2015; and 25 July 2016). The instrument was set to compression mode. During the test, each OSR pod was put in a special holder and fixed. The probe diameter was $4 \mathrm{~mm}$. The OSR pod was bent with the testing machine bar by applying a quasi-static load of $1 \mathrm{~mm} \mathrm{~s}^{-1}$, until the two valves separated. The OSR pod was subject to bending by the analyzer rod until the two valves opened ("dehiscence"). The force and displacement required for pod dehiscence were registered on the Digital Texture Analyzer. The pods were selected at random from upper branches of OSR plants. The average value from 10 OSR pods was used to determine the force $(\mathrm{N})$ required for pod dehiscence.

\subsection{Moisture Determination of Seeds and Pod Valves at Harvest}

Each year, on the day of the OSR harvest, five samples of seed and pod valves from five different plots (Figure 1) were taken for moisture content measurement. The moisture content was determined by weighing the seeds and pod valves before and after drying at $105^{\circ} \mathrm{C}$ until a constant weight was achieved.

\subsection{Determination of OSR Seed Losses Prior to Harvesting}

Each year, on the day after sealant application, evaluation of the spontaneous (natural) loss of seed was determined by placing 10 trays (each $1.50 \times 0.10 \mathrm{~m}$ ) on the soil surface within each plot. Each tray surface was covered with particular material so that fallen seeds did not bounce off the tray [36]. Every day until the day of harvest, all seeds were simultaneously collected from the trays and used to determine seed losses from different plots (a total of 50 samples every day). Natural OSR seed losses $\left(N, \mathrm{~kg} \mathrm{ha}^{-1}\right)$ were measured using following the equation:

$$
N=\frac{T S M \cdot n}{100 \cdot A}, \mathrm{~kg} \mathrm{ha}^{-1}
$$

TSM: 1000-seed mass, g;

$n$ : number of seeds per tray;

$A$ : area of the tray, $\mathrm{m}^{2}\left(\mathrm{~A}=0.15 \mathrm{~m}^{2}\right)$.

$$
N=\frac{10 \cdot m}{A}, \mathrm{~kg} \mathrm{ha}^{-1}
$$

m: mean mass of seed per tray, g.

Seed losses were expressed at $9 \%$ moisture content.

\subsection{Determination of OSR Seed Losses during Harvesting}

Rapeseed pod resistance in the field can be determined using various methods: seed counting after harvest, count shattered silique, manual bending of silique, vibrate whole plants, etc. [14]. The method used to determine seed losses during harvesting involved crop treatment with a specially developed tractor-mounted reel, which imitated the impact of combine harvester reel tines on OSR pods during 
harvesting (Figure 2). Reel plates with attached tines were rotated by the hydraulic motor. The tractor was driven along the paths in the trial field (Figure 1) at $4 \mathrm{~km} \mathrm{~h}^{-1}$. The ratio of reel tine linear speed and tractor drive speed was equal to 1.1. Eight trays (each $1.50 \times 0.10 \mathrm{~m}$ ) were placed on the soil at every $3 \mathrm{~m}$ in each test plot for evaluating seed losses. Tests were performed after the crop had reached full maturity (23 July 2014; 27 July 2015; and 25 July 2016). Tests were repeated three times in each plot.

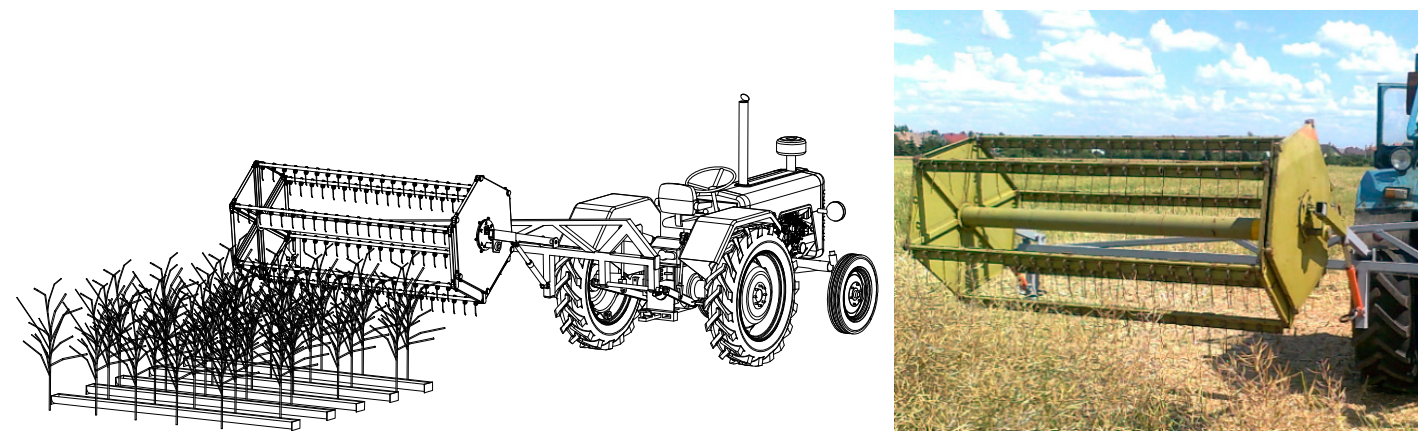

Figure 2. Combine harvester reel mobile stand: schematic view and in the field.

\subsection{Economic Evaluation of Pod Sealants Use}

The fixed costs necessary for pod sealant use were calculated. They comprised the sealant price, spraying unit rental price, fuel costs, and operator's wages (Table 1). By summing up these costs, the total sealant price for 1 ha of OSR was calculated, and the costs in all 3 years of experiments (2014, 2015, and 2016) were found to be similar.

Table 1. Costs indicators.

\begin{tabular}{cccccc}
\hline \multirow{2}{*}{ Indicators } & \multirow{2}{*}{$\begin{array}{c}\text { Unit of } \\
\text { Measurement }\end{array}$} & \multicolumn{4}{c}{ Sealant Types } \\
\cline { 3 - 6 } & $€ \mathrm{ha}^{-1}$ & 15.42 & 19.27 & 13.23 & 14.72 \\
\hline \multirow{2}{*}{ Sealant price } & $€ \mathrm{~h}^{-1}$ & 17.38 & 17.38 & 17.38 & 17.38 \\
\multirow{2}{*}{ Equipment rental } & $€ \mathrm{ha}^{-1}$ & 1.74 & 1.74 & 1.74 & 1.74 \\
\hline \multirow{2}{*}{ Fuel costs } & $€ \mathrm{ha}^{-1}$ & 1.50 & 1.50 & 1.50 & 1.50 \\
\hline \multirow{2}{*}{ Wages } & $€ \mathrm{~h}^{-1}$ & 4.34 & 4.34 & 4.34 & 4.34 \\
& $€ \mathrm{ha}^{-1}$ & 0.43 & 0.43 & 0.43 & 0.43 \\
\hline Total costs & $€ \mathrm{ha}^{-1}$ & 18.39 & 22.94 & 16.90 & 19.09 \\
\hline
\end{tabular}

Natural seed loss prior to harvest and seed loss during harvesting due to the impact of the combine harvester reel tines were also evaluated. After evaluating losses, seed yield per hectare was calculated. The purchase price of seeds each year at $9 \%$ moisture content was: $€ 318.58 \mathrm{t}^{-1}$ (2014), $€ 318.58 \mathrm{t}^{-1}$ (2015), and $€ 347.54 \mathrm{t}^{-1}$ (2016). Seed yield multiplied by purchase price determined the revenue for seed harvested. Any change in revenue achieved using different sealants was calculated later in comparison with the control plots, i.e., from the 1-ha area of OSR treated without a sealant. The profitability of OSR pod sealant use was calculated from the difference between revenue and expenses (Table 1).

\subsection{Environmental Evaluation of Pod Sealants Use}

The life cycle assessment analysis (LCA) was carried in accordance with ISO 14040 and ISO 14044 (ISO, 2006; ISO, 2006a). The function unit (FU) of this study was defined as $1 \mathrm{t}$ of rapeseed. The Simapro code database 8.0.4.30 of Pré Consultants [61,62] was used to assess the environmental performance of the five WOSR production systems (described in 2.1. Pod Sealant Field Trials) which form the focus of this study. The effect of pod sealants on global warming emission $\left(\mathrm{CO}_{2} \mathrm{eq} \mathrm{kg}\right)$ was investigated over the lifecycle of WOSR cultivation. 


\subsection{Statistical Analysis}

Data points are presented as mean values, their confidence levels, and the least significant difference $R_{0.05}$ (posthoc test LSD) were calculated at $95 \%$ probability with the statistical software Statistica 10.0.

\section{Results and Discussion}

\subsection{Weather Conditions and OSR Pod Strength}

One of the major factors determining pod shattering resistance and sealant efficacy is the force necessary for separating the OSR pod valves $[12,63,64]$. The primary factors causing variability in OSR pod strength are genetic traits, moisture, stage of ripeness, physical condition of the canopy, and environmental conditions [12]. Most studies use the opening force measurement to evaluate the genetic basis of spontaneous pod shattering resistance in varieties $[14,51,65,66]$ or to determine effects of fertilizer use and growing conditions on pod strength [67]. No study has evaluated the effectiveness of pod sealant in reducing losses due to pod shattering by measuring the force needed to separate OSR pod valves.

In this study, the meteorological parameters during the critical period of July-August 2014-2016 at different phonological stages $(\mathrm{BBCH})$ are presented in Figure $3 \mathrm{a}-\mathrm{c}$. Weather conditions during the three research years were different. In July 2014, it rained for 9 days (precipitation: $70.7 \mathrm{~mm}$ ), compared with 16 days in July 2015 (precipitation: $72.5 \mathrm{~mm}$ ) and 17 days in July 2016 (precipitation: $163.8 \mathrm{~mm}$ ). Monitoring of the average air temperature, relative air humidity, and wind speed till the date of OSR harvest revealed that the most favorable weather conditions for OSR were in 2014 and the least favorable were in 2016.

The force required to achieve OSR pod valve separation can vary from 0.3 to $6.0 \mathrm{~N}$, depending on genetic differences, growing conditions, and other factors $[29,60,63,64,66]$. Our results suggest that the force necessary to open OSR pod valves depends on the sealant type and prevailing weather conditions. In each of the 3 years of trials, pods treated with the experimental sealant PS4 required the greatest force to induce shattering. The force required was significantly greater than that in the control pods and in the pods treated with PS2 and PS3 in each year, except PS1 in 2015 (Table 2). The seed moisture content in pods treated with PS4 was significantly lower than that in pods receiving any other treatment in all 3 years, except in the control pods in 2014. Further, pod valve moisture content in pods treated with PS4 was significantly lower than that in pods receiving any of the other treatments in all 3 years, except in the control pods in 2014, PS2-treated pods in 2014, and PS3-treated pods in 2016 (Table 2).

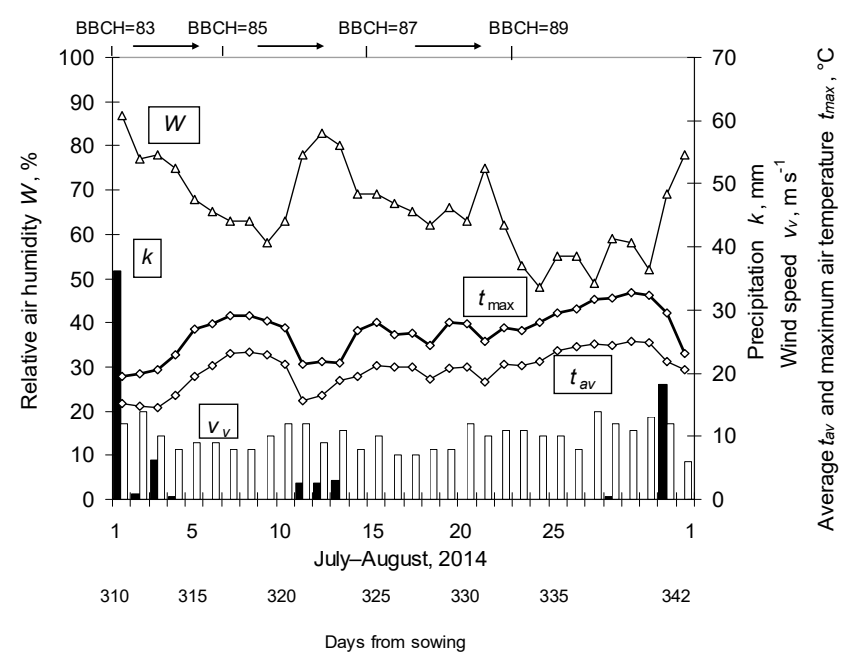

(a)

Figure 3. Cont. 


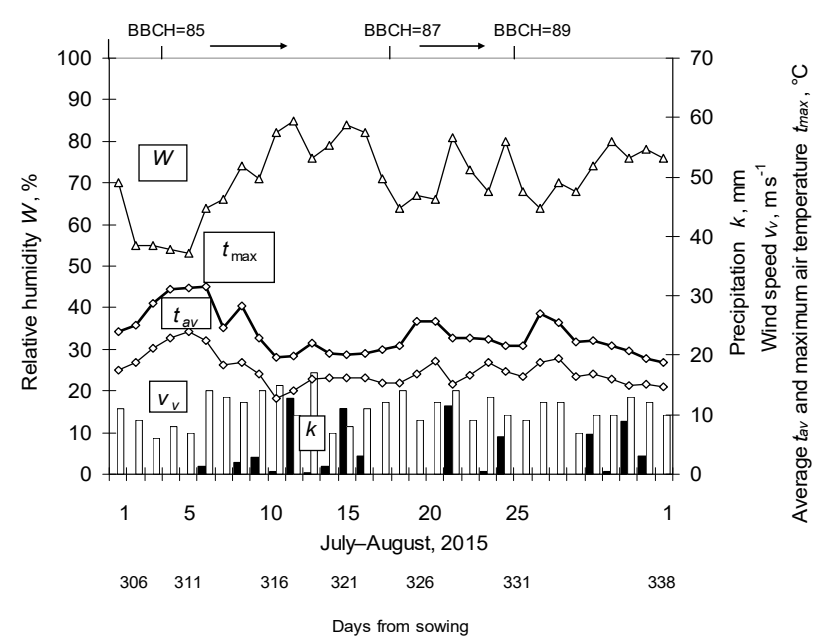

(b)

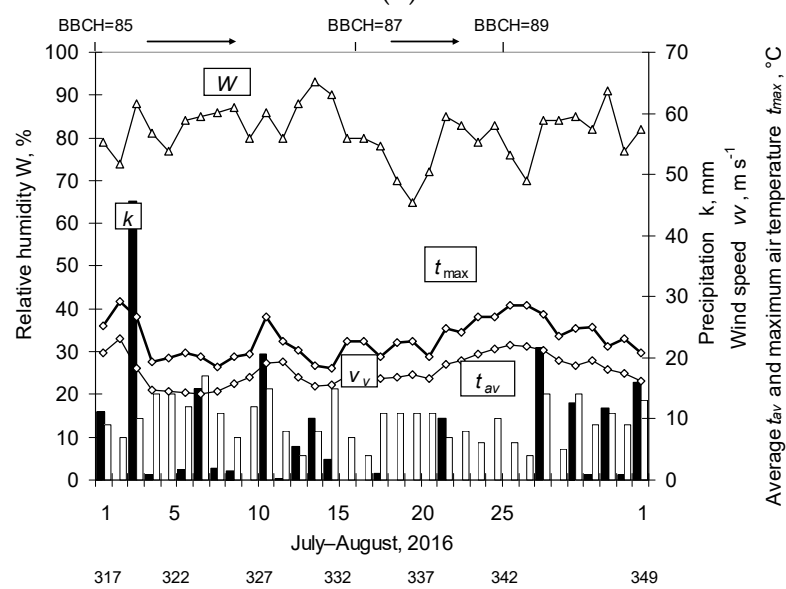

(c)

Figure 3. Weather conditions in 2014 (a), 2015 (b), and 2016 (c).

Table 2. Effect of pod sealant on moisture content (mean $\pm 95 \%$ confidence level) of pod valves $(q)$ and seeds $(w)$ and the force $(F)$ necessary for pod opening at harvest in 2014, 2015, and 2016. Values with similar letters were not significantly different at $p<0.05$ significance level.

\begin{tabular}{|c|c|c|c|c|c|}
\hline & PS1 & PS2 & PS3 & PS4 & Control \\
\hline \multirow{6}{*}{$\begin{array}{c}\text { OSR seed } \\
\text { moisture } W, \%\end{array}$} & & \multicolumn{4}{|c|}{23 July 2014 (LSD 0.29\%) } \\
\hline & $10.49 \pm 0.52$ & $8.78 \pm 0.11$ & $10.02 \pm 0.20$ & $8.35 \pm 0.16$ & $8.50 \pm 0.17$ \\
\hline & & \multicolumn{4}{|c|}{27 July 2015 (LSD 0.18\%) } \\
\hline & $14.17 \pm 0.10$ & $14.50 \pm 0.26^{\mathrm{a}}$ & $14.49 \pm 0.21^{\mathrm{a}}$ & $12.72 \pm 0.09$ & $16.35 \pm 0.15$ \\
\hline & & \multicolumn{4}{|c|}{25 July 2016 (LSD $0.59 \%)$} \\
\hline & $20.99 \pm 1.13$ & $18.50 \pm 0.07$ & $18.73 \pm 0.26$ & $17.85 \pm 0.21$ & $20.64 \pm 0.35$ \\
\hline \multirow{6}{*}{$\begin{array}{l}\text { OSR pod valve } \\
\text { moisture } q, \%\end{array}$} & & \multicolumn{4}{|c|}{23 July 2014 (LSD 5.31\%) } \\
\hline & $25.07 \pm 4.47$ & $21.53 \pm 7.61$ & $28.52 \pm 2.77$ & $21.79 \pm 5.14$ & $18.57 \pm 3.58$ \\
\hline & & \multicolumn{4}{|c|}{27 July 2015 (LSD $2.54 \%)$} \\
\hline & $26.00 \pm 1.51^{b}$ & $18.83 \pm 2.29^{a}$ & $19.11 \pm 1.84^{\mathrm{a}}$ & $15.91 \pm 0.98^{a}$ & $27.77 \pm 4.08^{b}$ \\
\hline & & \multicolumn{4}{|c|}{25 July 2016 (LSD $2.10 \%)$} \\
\hline & $29.26 \pm 2.99 \mathrm{ab}$ & $30.07 \pm 1.72^{b}$ & $27.41 \pm 1.88^{a}$ & $27.38 \pm 0.90^{a}$ & $32.64 \pm 1.83$ \\
\hline \multirow{5}{*}{ Force $F, \mathrm{~N}$} & & \multicolumn{4}{|c|}{23 July 2014 (LSD 0.18 N) } \\
\hline & $1.87 \pm 0.16^{\mathrm{a}}$ & $1.96 \pm 0.17^{\mathrm{a}}$ & $1.84 \pm 0.11^{\mathrm{a}}$ & $2.16 \pm 0.15$ & $1.96 \pm 0.10^{\mathrm{a}}$ \\
\hline & & \multicolumn{4}{|c|}{27 July 2015 (LSD 0.27 N) } \\
\hline & $2.28 \pm 0.29 \mathrm{ab}$ & $2.12 \pm 0.21^{b}$ & \multicolumn{2}{|c|}{25 July 2016 (LSD 0.12 N) } & $1.85 \pm 0.20^{\mathrm{c}}$ \\
\hline & $1.44 \pm 0.11^{\mathrm{a}}$ & $1.55 \pm 0.07^{\mathrm{a}}$ & $1.50 \pm 0.10^{\mathrm{a}}$ & $1.70 \pm 0.10$ & $1.46 \pm 0.09^{a}$ \\
\hline
\end{tabular}


Weather conditions for harvest of OSR pods were least favorable in the summer of 2016 due to heavy precipitation (Figure 3c). On the harvest day in 2016, OSR pod valves had a mean moisture content of $30 \%$ and the force necessary to separate the OSR pod valves was $20 \%$ lower than that in 2015. The data showed that the increase of relative air humidity and precipitation in the summer of 2016 (precipitation was $49.8 \mathrm{~mm}$ in the second half of July 2016 (Figure 3c)) was associated with a decrease in the force $(F)$ required. A mechanism by which OSR pod drying potentiates shattering has been described by Spence et al. [68] and Squires et al. [59].

It was clear that during each of the trial years, the force required for opening of PS4-treated OSR pod valves was $10-20 \%$ higher than that for the pods from the other treatments, whereas the seed moisture content was approximately $14 \%$ lower and the pod valve moisture content $34 \%$ lower than those exhibited by pods from the other treatments. Previous research has shown that a pinolen-based pod sealant sprayed 2 weeks prior to OSR harvest has no effect on the dynamics of seed moisture content within the pods [36].

\subsection{Seed Losses Due to Spontaneous Shattering Prior to Harvesting}

Seeds that are shed prior to harvesting due to pod shattering are regarded as a natural loss [12]. There is a lack of research on pod sealant influence on such natural (or spontaneous) shattering. Studies examining the effect of different pod sealants on natural and harvesting losses of seed have reported that their efficacy is highly influenced by weather conditions, OSR variety characteristics, and other factors $[23,27,39]$. Some research has shown that by delaying OSR harvesting, natural losses in the non-treated crops increase faster than in the sealant-treated crops $[21,27,36]$.

In the current study, natural seed losses were determined by collecting seeds in trays from the spraying day to the day of harvest. The pod sealants reduced the natural seed losses. The highest natural seed losses (mean $\pm 95 \%$ confidence level) in 2014 occurred in the control field plots ( $46.3 \pm 16.1 \mathrm{~kg} \mathrm{ha}^{-1}$, accounting for $1.49 \% \pm 0.52 \%$ of the total prospective yield), whereas the lowest losses were in plots sprayed with PS4 $\left(14.9 \pm 4.8 \mathrm{~kg} \mathrm{ha}^{-1}\right.$ or $\left.0.48 \% \pm 0.15 \%\right)$ or PS3 $\left(19.9 \pm 6.6 \mathrm{~kg} \mathrm{ha}^{-1}\right.$ or $\left.0.64 \% \pm 0.21 \%\right)$ (Figure 4a). All four pod sealants resulted in significant decreases in natural seed loss compared with the control treatment, but the differences in seed loss between the different sealants were not significant (Figure 4a).

The weather conditions were worse in 2015 than in 2014, and spontaneous seed losses were higher in 2015 than in 2014 (Figure 4b). Maximum natural seed losses occurred in the control plots (115.2 $\pm 27.2 \mathrm{~kg} \mathrm{ha}^{-1}$, equivalent to $3.29 \% \pm 0.80 \%$ of the total seed yield), whereas the minimum seed losses occurred in plots sprayed with PS4 $\left(36.4 \pm 10.5 \mathrm{~kg} \mathrm{ha}^{-1}\right.$, or $\left.1.04 \% \pm 0.30 \%\right)$ or PS1 $\left(42.8 \pm 12.4 \mathrm{~kg} \mathrm{ha}^{-1}\right.$, or $\left.1.22 \% \pm 0.36 \%\right)$. Treatment with any of the four sealants resulted in a significant decrease in seed loss compared with by the control treatment, with the losses in plots treated with PS2 or PS3 being significantly greater than those in plots treated with PS4 or PS1 (Figure $4 \mathrm{~b}$ ).

Weather conditions in 2016 were the worst among the 3 years of trial, resulting in the highest spontaneous seed losses due to pod shattering observed during the entire study period. Maximum natural seed losses in 2016 (Figure 4c) occurred in the control field (227.4 $\pm 80.2 \mathrm{~kg} \mathrm{ha}^{-1}$, accounting for $8.12 \% \pm 2.87 \%$ of the total seed yield), whereas the lowest seed losses $\left(130.9 \pm 39.1 \mathrm{~kg} \mathrm{ha}^{-1}\right.$, or $4.67 \% \pm 1.40 \%$ ) occurred in the plots sprayed with sealant PS4. Treatment with only PS4 and PS2 resulted in significant reductions in seed losses compared with losses by the control treatment, whereas the losses in the PS4-treated plots were significantly lower than those in the PS2-treated plots (Figure 4c).

In summary, it was clear from the results of 2014-2016 that pods sprayed with PS4 were the most resistant to spontaneous shattering and subsequent seed loss, resulting in three-fold reduction in seed loss compared with that by the control treatment. Although treatment with all three commercial pod sealants resulted in a significant reduction (compared with the control treatment) in spontaneous pod shattering under good (2014) and moderate (2015) weather conditions, only PS2 reduced seed losses 
under the poor weather conditions of 2016. In contrast, treatment with PS4 resulted in the lowest seed losses in each year.

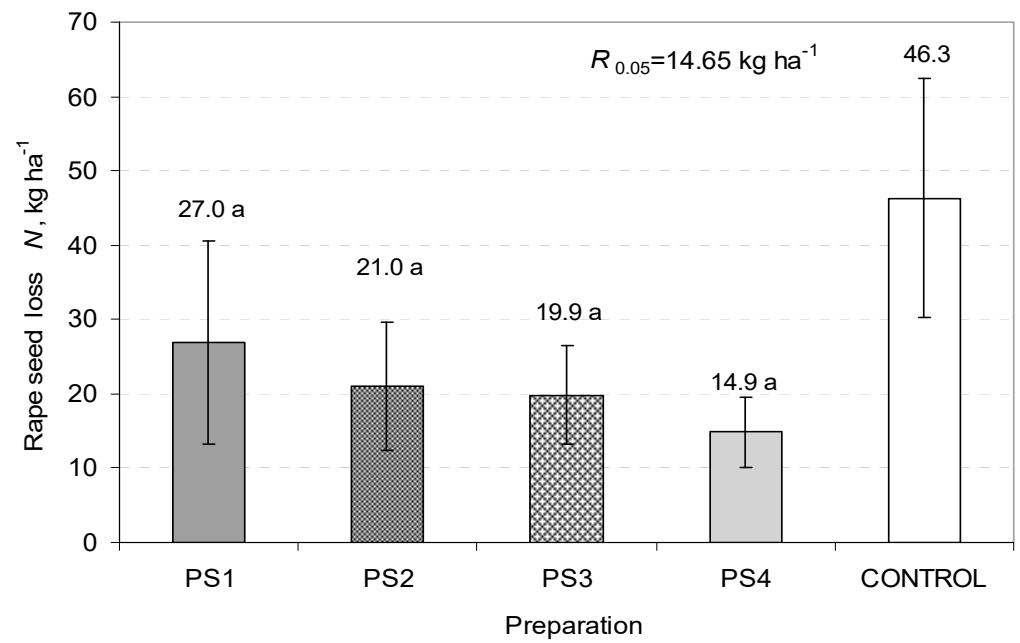

(a)

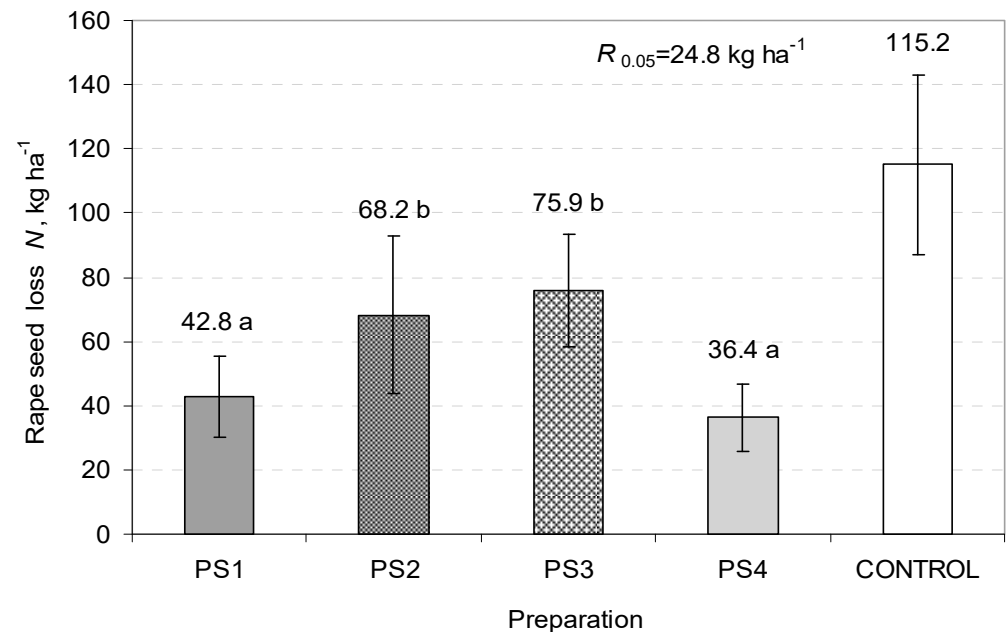

(b)

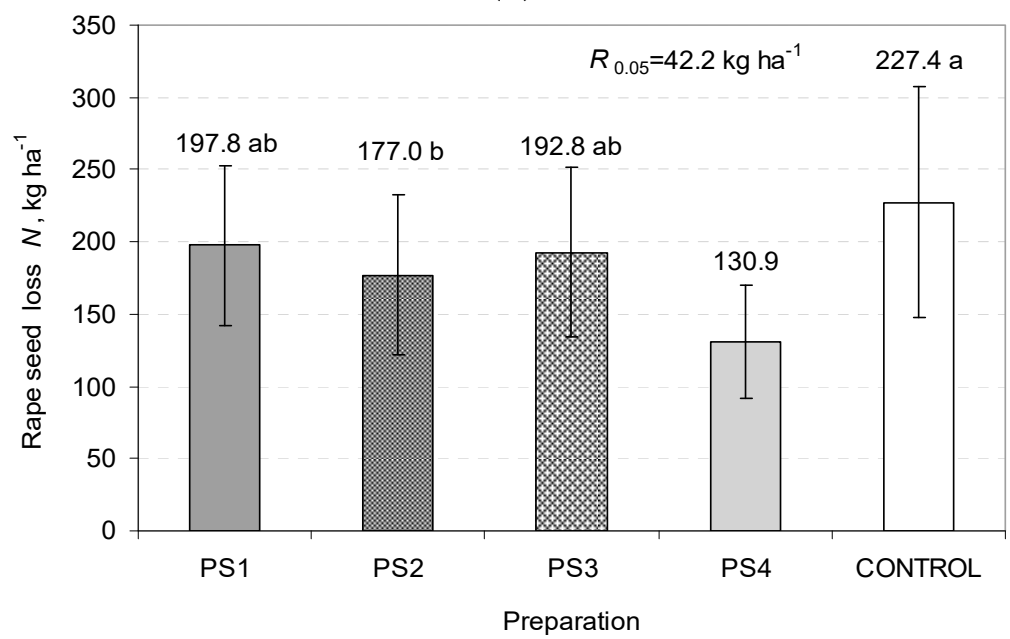

(c)

Figure 4. Seed losses due to spontaneous pod shattering $N\left(\mathrm{~kg} \mathrm{ha}^{-1}\right)$ in 2014 (a), 2015 (b), and 2016 (c). Any two samples with a common letter are not significantly different $(p>0.05)$, as assessed using least significant difference. 
The strength of PS4-treated pods increased most likely due to the presence of the acrylic dispersion, a component of PS4 that covers the pod with a resilient film. However, this material does not ensure good solution coverage over the pod surface [69], so a second component (trisiloxane) that lowers the dynamical surface tension of spray solutions was added [38], ensuring quick spreading of the solution across the pod surface. Rapid spreading was achieved by the formation of extremely thick wetting films and partly by long-range electrostatic forces [70]. One study has reported that after reducing the surface tension of the solution adding the surfactant trisiloxane, the quantity of the liquid maintained on leaves of rice plants increases [71].

\subsection{Seed Losses Due to Shattering during Harvesting}

The upper limit of seed losses by harvesting cereals with modern self-propelled combine harvesters is $1 \%$ [24]. Harvesting losses of OSR depend on the type of harvesting, namely direct harvest or swathing [23,34]. Research has shown that seed losses at harvesting in spring OSR were from 1.7 to $4.9 \%$ for direct harvest OSR and from 2.6 to $4.6 \%$ for swathed OSR [34]. The main variables affecting harvesting losses are the combine harvester reel rotation frequency, reel tine impact on the pods, dynamic forces of active separators on the cutter table, and driving speed of the combine harvester. These impacts (and subsequent seed loss) can be reduced by changing the reel tine shape and covering its surface with elastic material as well as by reducing the combine harvester driving speed and reel rotation frequency. By attaching active separators to the cutter table, seed losses can be reduced $[24,36]$. Reportedly, by installing a belt elevator in the combine harvester behind the cutting unit of the cutter table, harvesting losses can be reduced [35].

There is also a lack of research on the influence of pod sealants on OSR losses during harvesting. Using combine harvesters to direct-harvest mature spring OSR, the effect of a pinolen-based pod sealant on shattering loss from harvesting is reportedly not substantial [36], whereas Haile et al. [23] have shown that two pod sealants did not affect seed shattering during direct harvest under Canadian Prairie conditions.

Our study suggests that in both 2014 and 2015, seed losses due to the impact of reel tines depended on the type of sealant. These losses were significantly higher than losses due to natural shattering.

Unlike the situation with spontaneous pod shattering, the relative rankings of the effects of pod treatments on mean seed loss due to pod shattering at harvest were largely consistent across the 3 years of study, with the greatest losses occurring in the control plots $\left(177.8 \mathrm{~kg} \mathrm{ha}^{-1}\right.$ or $5.74 \%$ in 2014 , $692.9 \mathrm{~kg} \mathrm{ha}^{-1}$ or $19.8 \%$ in 2015 , and $439.8 \mathrm{~kg} \mathrm{ha}^{-1}$ or $15.7 \%$ in 2016) and the smallest losses in the PS4-treated plots ( $40.8 \mathrm{~kg} \mathrm{ha}^{-1}$ or $1.32 \%$ in $2014,242.4 \mathrm{~kg} \mathrm{ha}^{-1}$ or $6.93 \%$ in 2015 , and $223.5 \mathrm{~kg} \mathrm{ha}^{-1}$ or $8.0 \%$ in 2016) (Figure 5a-c). Compared with the control treatment, each of the pod sealants significantly reduced seed losses in each year, with PS4 having significantly better effects than all other pod sealants, except in 2016 when the seed losses in PS4- or PS1-treated plots were not significantly different (Figure 5c).

As with the effect on pre-harvest spontaneous pod shattering, the experimental sealant PS4 proved to be the most-effective product tested in reducing seed loss during harvest. Interestingly, the advantage of PS4 was least in 2016, when the weather was poor. Efficacy of the pod sealants varied, depending on the weather conditions, which were markedly different across the 3 years of trial. Adverse weather conditions in 2016 influenced pod valve strength, natural shattering loss, and seed losses during harvesting. This confirms the conclusions of other studies, that OSR pod strength correlates negatively with OSR seed loss $[29,55,60]$. 


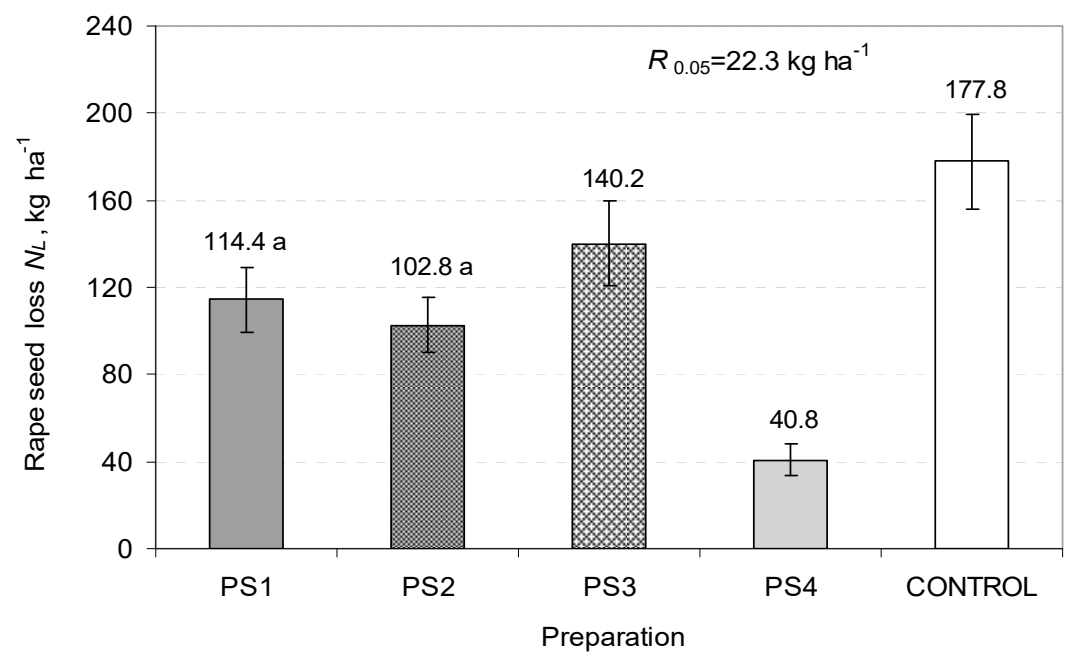

(a)

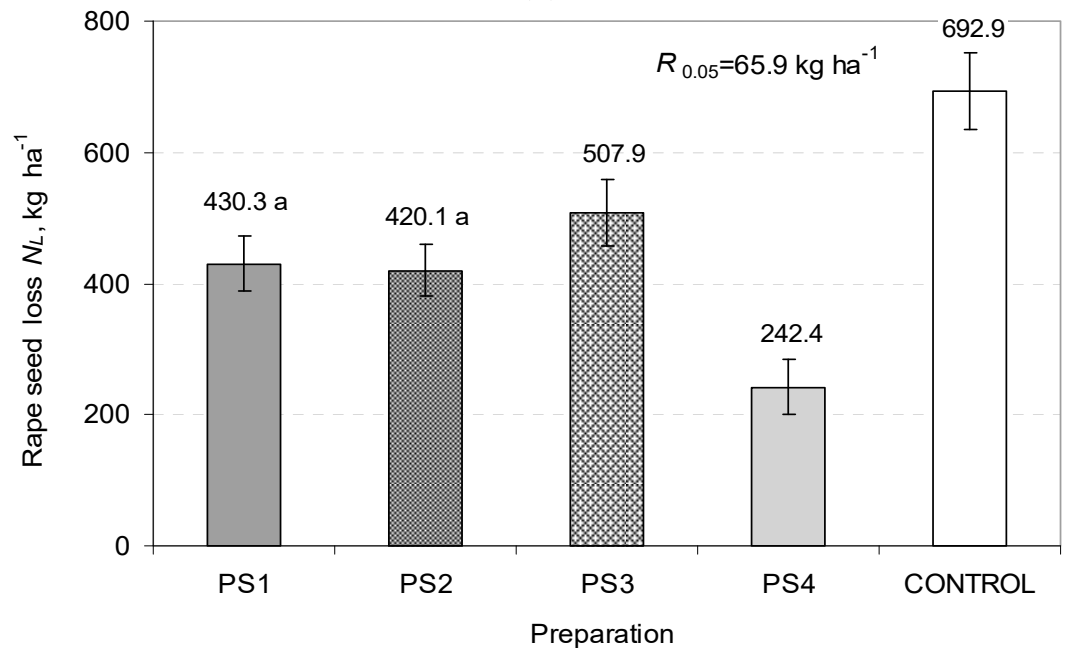

(b)

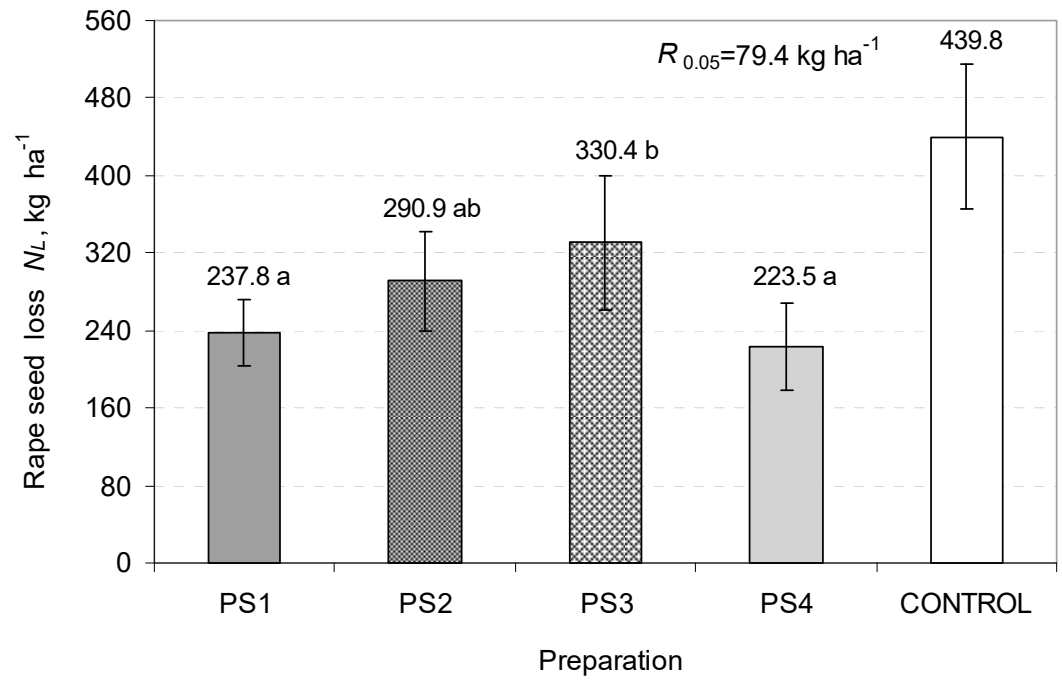

(c)

Figure 5. Mean seed losses ( $\pm 95 \%$ confidence limits) due to pod shattering at harvest caused by combine harvester reel tine impact $N_{L}\left(\mathrm{~kg} \mathrm{ha}^{-1}\right)$ in 2014 (a), 2015 (b), and 2016 (c). Any two samples with a common letter are not significantly different at the $p<0.05$ level. 


\subsection{Economic Evaluation of Pod Sealant Use}

Previous studies on the effectiveness of pod sealants on OSR seed losses have produced quite contradictory results $[23,27,36,38,39]$. The consensus indicates that pod sealants should be applied on OSR if harvesting is delayed [21,36]. While evaluating pod sealant efficacy, it is also necessary to consider that during application of sealants, passage of a tractor and sprayer or a self-propelled sprayer can cause damage to the near-mature OSR plants, potentially triggering further pod shattering and seed loss. Another issue that potentially needs to be addressed is whether the effect of sealant application on valve closure negatively affects the release of seeds from harvested pods, lowering the seed yield. Further research needs to address these and other issues.

Recommendation of the use of pod sealants should take into account the net benefit of the treatment to the farmer. After taking into account fuel, sealant, wages, and other costs, some studies have recommended spraying OSR with a pinolen-based pod sealant only in exceptional circumstances [36]. Therefore, to precisely evaluate the viability of the use of the four sealants tested, it was important to calculate the cost-effectiveness of the treatments.

In this study, general costs for the use of different sealants did not differ significantly (Table 3); the only difference was the purchase price of the individual sealants.

Table 3. Economic indicators.

\begin{tabular}{|c|c|c|c|c|c|c|c|c|}
\hline \multirow[b]{2}{*}{ Sealant Options } & \multirow[b]{2}{*}{$\begin{array}{c}\text { Seed } \\
\text { Losses, } \\
\text { kg ha }^{-1}\end{array}$} & \multicolumn{2}{|c|}{ Of Which: } & \multirow[b]{2}{*}{$\begin{array}{l}\text { Seed Yield, } \\
\mathrm{kg} \mathrm{ha}^{-1}\end{array}$} & \multirow[b]{2}{*}{$\begin{array}{c}\text { Revenue, } \\
€ \text { ha }^{-1}\end{array}$} & \multirow[b]{2}{*}{$\begin{array}{l}\text { Loss Reduction } \\
\text { Compared with } \\
\text { Control, } € \text { ha }^{-1}\end{array}$} & \multirow[b]{2}{*}{$\begin{array}{l}\text { General Costs } \\
\text { for Sealant } \\
\text { Use, } € \text { ha }^{-1}\end{array}$} & \multirow[b]{2}{*}{$\begin{array}{l}\text { Profit, } \\
€ \text { ha }^{-1}\end{array}$} \\
\hline & & $\begin{array}{l}\text { Prior } \\
\text { Harvest, } \\
\text { kg ha }^{-1}\end{array}$ & $\begin{array}{l}\text { HARVEST } \\
\text { (Reel), } \\
\mathrm{kg} \mathrm{ha}^{-1}\end{array}$ & & & & & \\
\hline \multicolumn{9}{|c|}{2014} \\
\hline Control & 224.1 & 46.3 & 177.8 & 2875.9 & 916.21 & 0.00 & - & - \\
\hline PS1 $6.25 \mathrm{~g} \mathrm{~kg}^{-1}$ & 141.3 & 27.0 & 114.4 & 2958.7 & 942.59 & 26.37 & 18.39 & 7.98 \\
\hline PS2 $5.00 \mathrm{~g} \mathrm{~kg}^{-1}$ & 123.8 & 21.0 & 102.8 & 2976.2 & 948.17 & 31.96 & 22.94 & 9.02 \\
\hline PS3 $6.50 \mathrm{~g} \mathrm{~kg}^{-1}$ & 160.0 & 19.9 & 140.2 & 2940.0 & 936.62 & 20.41 & 16.90 & 3.50 \\
\hline PS4 $2.00 \mathrm{~g} \mathrm{~kg}^{-1}$ & 55.7 & 14.9 & 40.8 & 3044.3 & 969.87 & 53.66 & 19.09 & 34.57 \\
\hline \multicolumn{9}{|c|}{2015} \\
\hline Control & 808.1 & 115.2 & 692.9 & 2691.9 & 857.59 & 0.00 & - & - \\
\hline PS1 $6.25 \mathrm{~g} \mathrm{~kg}^{-1}$ & 473.1 & 42.8 & 430.3 & 3026.9 & 964.32 & 106.73 & 18.39 & 88.34 \\
\hline PS2 $5.00 \mathrm{~g} \mathrm{~kg}^{-1}$ & 488.3 & 68.2 & 420.1 & 3011.7 & 959.47 & 101.88 & 22.94 & 78.93 \\
\hline PS3 $6.50 \mathrm{~g} \mathrm{~kg}^{-1}$ & 583.7 & 75.9 & 507.9 & 2916.3 & 939.07 & 71.47 & 16.90 & 54.57 \\
\hline PS4 $2.00 \mathrm{~g} \mathrm{~kg}^{-1}$ & 278.7 & 36.4 & 242.4 & 3221.3 & 1026.23 & 168.64 & 19.09 & 149.55 \\
\hline \multicolumn{9}{|c|}{2016} \\
\hline Control & 667.2 & 227.4 & 439.8 & 2132.8 & 741.24 & 0.00 & - & - \\
\hline PS1 $6.25 \mathrm{~g} \mathrm{~kg}^{-1}$ & 435.7 & 197.8 & 237.8 & 2364.3 & 821.71 & 80.47 & 18.39 & 62.08 \\
\hline PS2 $5.00 \mathrm{~g} \mathrm{~kg}^{-1}$ & 467.9 & 177.0 & 290.9 & 2332.1 & 810.51 & 69.27 & 22.94 & 46.33 \\
\hline PS3 $6.50 \mathrm{~g} \mathrm{~kg}^{-1}$ & 523.2 & 192.8 & 330.4 & 2276.8 & 791.28 & 50.04 & 16.90 & 33.14 \\
\hline PS4 $2.00 \mathrm{~g} \mathrm{~kg}^{-1}$ & 354.4 & 130.9 & 223.5 & 2445.6 & 849.96 & 108.73 & 19.09 & 89.64 \\
\hline
\end{tabular}

After evaluation of seed loss (spontaneous (pre-harvest) and at harvest) and costs for sealant use, the calculated efficiency of sealant use is expressed as additional revenue or profit. Sealant use analysis showed that sealant effectiveness depends highly on weather conditions, which differed markedly among the 3 years of the study (Table 3). All sealants were economically viable each year. After spraying OSR with PS2 in 2014, under good weather conditions, additional net income was $€ 9.02 \mathrm{ha}^{-1}$ compared with $€ 34.57 \mathrm{ha}^{-1}$ (almost 3.5 times more) after spraying with PS4. In 2015 with moderate weather conditions, the corresponding figures were $€ 78.93 \mathrm{ha}^{-1}$ for PS2 and $€ 149.55 \mathrm{ha}^{-1}$ for PS4, whereas under poor weather conditions of 2016, the corresponding figures were $€ 46.33 \mathrm{ha}^{-1}$ for PS2 and $€ 89.64 \mathrm{ha}^{-1}$ for PS4.

\subsection{Environmental Evaluation of Pod Sealants Use}

In this study, the functional unit was considered to be one ton of WOSR seed production. The life cycle assessment method as a tool for quantitative assessing the environmental effects of production of 
one ton of WOSR was used in this study. At first, the total energy consumption was calculated. Energy input-output analysis also called energy balance analysis is usually used to evaluate the efficiency and environmental impacts of OSR cultivation. Table 4 shows values of total energy consumption in 2014, 2015, and 2016. Average energy consumption for PS4 (1680.2 $\left.\pm 125.9 \mathrm{MJ} \mathrm{t}^{-1}\right)$ was from 2.6 to $5.7 \%$ less as compared with other pod sealants and $17.8 \%$ less as compared with the control.

Table 4. Effect of pod sealant on total (direct and indirect) energy consumption (MJ $\mathrm{t}^{-1}$ ) in 2014, 2015, and 2016.

\begin{tabular}{cccccc}
\hline \multirow{2}{*}{ Year } & \multicolumn{5}{c}{ Average Energy Consumption, $\mathbf{M J ~ t}^{\mathbf{- 1}}$ or MJ FU $^{\mathbf{- 1}}$} \\
\cline { 2 - 6 } & PS1 & PS2 & PS3 & PS4 & Control \\
\hline 2014 & 1559.2 & 1640.0 & 1639.5 & 1593.2 & 1821.7 \\
2015 & 1615.0 & 1623.2 & 1651.1 & 1519.0 & 1930.6 \\
2016 & 2000.9 & 2031.8 & 2053.7 & 1928.3 & 2382.0 \\
$2014-2016$ & $1725.0 \pm 138.8$ & $1765.0 \pm 133.5$ & $1781.4 \pm 136.2$ & $1680.2 \pm 125.9$ & $2044.8 \pm 171.5$ \\
\hline
\end{tabular}

Analyzing the energy consumption by inputs, it is evident that among all inputs, fertilizing (with NPK) is the most energy consuming one (Figure 6). This consists of $43.20 \% \pm 1.93 \%$ of the total energy input for WOSR cultivation. The results are comparable with results of Mousavi-Avval et al. [72]. They indicated that nitrogen fertilizers are about $47 \%$ of the total energy input. Thus, to reduce environmental impacts of WOSR production, it should become more efficient regarding fertilizer use.

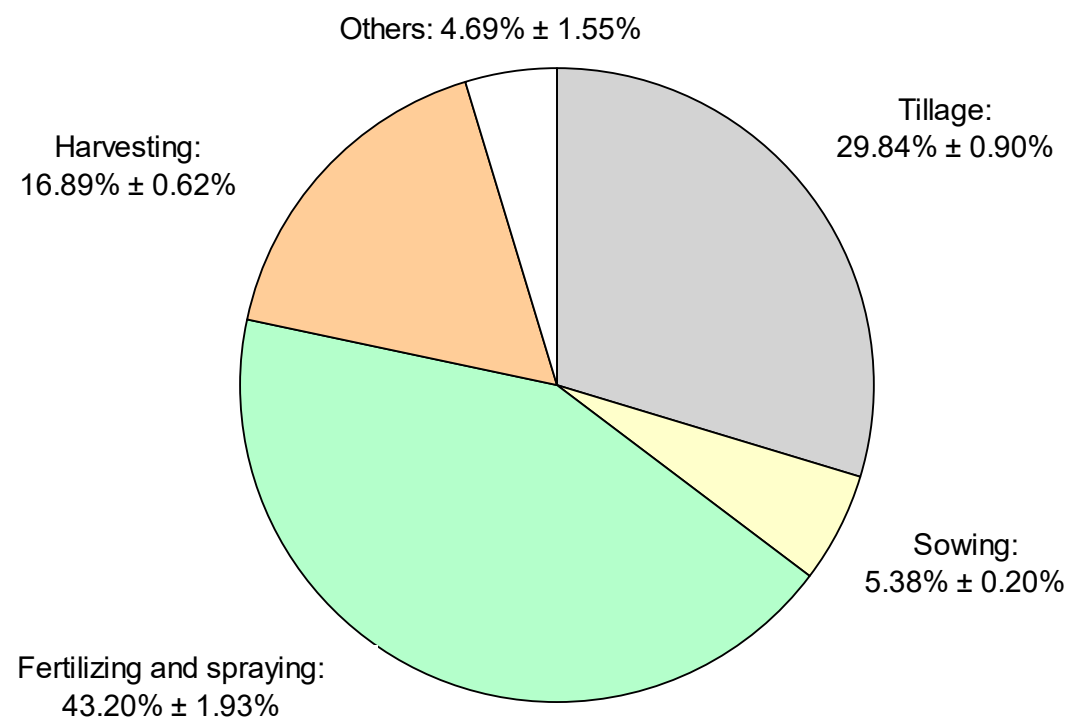

Figure 6. Average percentage of the farm machinery operations (with materials: seeds, fertilizers, pesticides, sealants etc.) on total energy consumption (MJ t ${ }^{-1}$ ) in 2014, 2015, and 2016.

Depending on the loss and yield of WOSR occurred each year; a different area (ha) is needed to produce $1 \mathrm{t}$ of WOSR seeds. In this study $0.35 \pm 0.10$ ha of area was needed to produce $1 \mathrm{t}$ of WOSR seeds by applying PS4 as shown in Table 5.

Table 5. Effect of pod sealant on area (ha) needed to produce $1 \mathrm{t}$ of winter oilseed rape (WOSR) seeds in 2014-2016.

\begin{tabular}{cccccc}
\hline \multirow{2}{*}{ Year } & \multicolumn{5}{c}{ Land Area, ha } \\
\cline { 2 - 6 } & PS1 & PS2 & PS3 & PS4 & Control \\
\hline $2014-2016$ & $0.36 \pm 0.09$ & $0.37 \pm 0.10$ & $0.37 \pm 0.10$ & $0.35 \pm 0.10$ & $0.40 \pm 0.12$ \\
\hline
\end{tabular}


The life cycle of each indirect energy input is included within the system boundaries, and considers tillage, sowing, fertilizing and spraying, harvesting, and others. Raw material extraction, production, waste management, transportation, and utilization are described as direct energy inputs. The amount of direct and indirect emissions is related to global warming emission $\left(\mathrm{kg} \mathrm{CO}_{2}\right.$ eq). Effect of pod sealant on global warming emission ( $\mathrm{kg} \mathrm{CO}_{2}$ eq) and WOSR seed yield $\left(\mathrm{kg} \mathrm{ha}^{-1}\right)$ in 2014, 2015, and 2016 are given in Table 6. The global warming emission differed among three years of experiments and mainly depending from seed yield (Table 6) and amount of fertilizer (Figure 6). In this study due to application of pod sealants the seed yield loss was reduced in different degrees. In all three research years, the highest seed yield and the lowest seed losses were achieved in the WOSR cultivation scenario with PS4 application (Table 6).

Table 6. Effect of pod sealant on global warming emission $\left(\mathrm{kg} \mathrm{CO}_{2} \mathrm{eq}\right)$ and WOSR seed yield $\left(\mathrm{kg} \mathrm{ha}^{-1}\right)$ in 2014, 2015, and 2016.

\begin{tabular}{|c|c|c|c|c|c|c|c|c|c|}
\hline \multicolumn{2}{|c|}{ PS1 } & \multicolumn{2}{|c|}{ PS2 } & \multicolumn{2}{|c|}{ PS3 } & \multicolumn{2}{|c|}{ PS4 } & \multicolumn{2}{|c|}{ Control (without PS) } \\
\hline \multicolumn{10}{|c|}{2014} \\
\hline 847.11 & 2958.7 & 852.50 & 2976.2 & 886.99 & 2940.0 & 805.78 & 3044.3 & 949.42 & 2875.9 \\
\hline 842.09 & 3026.9 & 849.53 & 3011.7 & 889.22 & 2916.3 & 792.58 & 3221.3 & 967.10 & 2691.9 \\
\hline \multicolumn{10}{|c|}{2016} \\
\hline 900.86 & 2364.3 & 921.54 & 2332.1 & 960.88 & 2276.8 & 865.20 & 2445.6 & 1042.36 & 2132.8 \\
\hline
\end{tabular}

Effect of pod sealants on global warming emission revealed that $\mathrm{CO}_{2}$ eq $\mathrm{kg}$ emitted over the lifecycle of WOSR cultivation could be decreased (Figure 7).

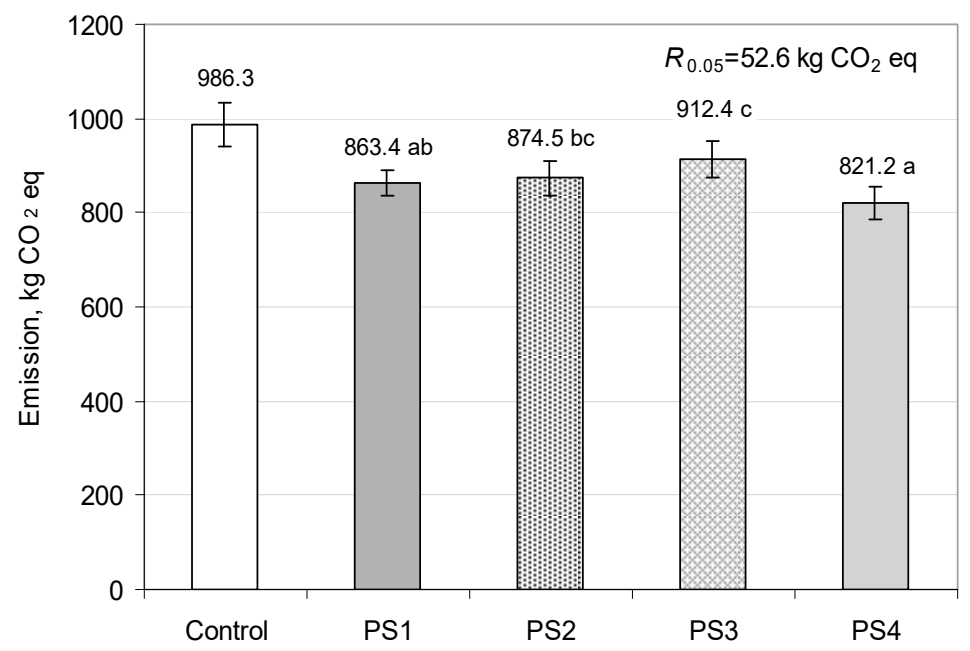

Figure 7. Effect of pod sealant on global warming emission ( $\left.\mathrm{kg} \mathrm{CO}_{2} \mathrm{eq}\right)$ during 2014-2016 WOSR cultivation. Values with similar letters were not significantly different at $p<0.05$ significance level.

The life cycle assessment showed that during 2014-2016 WOSR cultivation, the largest effect on global warming emission ( $\mathrm{kg} \mathrm{CO}_{2}$ eq) reduction was experimental sealant PS4, i.e., approximately $17 \%$ compared to the control.

\section{Conclusions}

Natural seed losses before harvest in the control plots (in the absence of sealants) were approximately $1.5 \%$ under good weather conditions of 2014, 3\% under wetter conditions of 2015, 
and $8 \%$ under very wet and windy conditions of 2016. When pods were sprayed with our developed experimental sealant PS4, which combines an acrylic sealant with a surfactant trisiloxane, 2 weeks prior to harvest, natural losses in the control plots could be reduced by $20-70 \%$.

Regardless of different weather conditions in 2014, 2015, and 2016, pods sprayed with PS4 on the day of harvesting showed approximately $14 \%$ lower seed moisture and approximately $34 \%$ lower pod valve moisture than those receiving other treatments.

The force necessary to open OSR valves depended on sealant composition and weather conditions in July. The required force decreased when precipitation occurred during the indicated period. The force necessary for opening the OSR pods during harvesting was $10-20 \%$ higher in pods sprayed with PS4 than in those sprayed with other sealants.

By spraying OSR with PS4, seed losses at harvest due to the impact of combine harvester reel tines could be reduced by up to three-fold from those in control plots. The economic viability of using a sealant on OSR varied according to year and, to some extent, weather conditions. Using the most-effective sealant PS4 for processing of pods, additional net income of $€ 30-€ 150 \mathrm{ha}^{-1}$ could be achieved. Comparing the economic viability of PS4 use to that of commercial sealants with different active ingredients, the differences in net additional income ranged from 3.5 to 9.5 times in 2014, from 1.7 to 2.7 times in 2015, and from 1.4 to 2.7 times in 2016.

The life cycle assessment showed that during 2014-2016 WOSR cultivation, the largest effect on global warming emission $\left(\mathrm{kg} \mathrm{CO}_{2}\right.$ eq) reduction was experimental sealant PS4, i.e., approximately $17 \%$ compared to the control.

Author Contributions: Conceptualization, E.Z., L.B., D.S. and A.K.; methodology, D.S., A.K., L.B. and E.Z.; investigation, D.S., A.K., L.B. and E.Z.; writing-review and editing, D.S., A.K., L.B. and E.Z.; visualization, D.S., A.K., L.B. and E.Z.; and supervision, D.S.

Funding: This research received no external funding.

Conflicts of Interest: The authors declare no conflict of interest.

\title{
Abbreviations
}

\author{
OSR Oilseed Rape \\ WOSR Winter Oilseed Rape \\ PS1 Terpene Polymer Pod Sealant \\ PS2 Carboxylated Styrene Butadiene Copolymer Pod Sealant with Alkyl Phenyl Hydroxyethylene \\ PS3 Turpentine Resin Pod Sealant \\ PS4 An Experimental Polyether-Polysiloxane Copolymer with a Styrol-Acrylate Copolymer-Based \\ Sealant
}

\section{References}

1. Assefa, Y.; Prasad, P.V.; Foster, C.; Wright, Y.; Young, S.; Bradley, P.; Stamm, M.; Ciampitti, I.A. Major management factors determining spring and winter canola yield in North America. Crop Sci. 2018, 58, 1-16. [CrossRef]

2. Rakow, G. Species origin and economic importance of Brassica. In Brassica; Pua, E.C., Douglas, C.J., Eds.; Springer: Berlin/Heidelberg, Germany, 2004; Volume 54, pp. 3-11.

3. Warwick, S.I. Brassicaceae in agriculture. In Genetics and Genomics of the Brassicaceae. Plant Genetics and Genomics: Crops and Models; Schmidt, R., Bancroft, I., Eds.; Springer: New York, NY, USA, 2011; Chapter 2; pp. 33-65.

4. Mitsis, T.; Efthimiadou, A.; Bilalis, D.J.; Danalatos, N.G.; Efthimiadis, P.; Konstantas, A. Maximizing oilseed rape's yield by glyphosate under Mediterranean conditions. Ind. Crops Prod. 2011, 33, 544-548. [CrossRef]

5. Thiyam, U.; Kuhlmann, A.; Stöckmann, H.; Schwarz, K. Prospects of rapeseed oil by-products with respect to antioxidative potential. C. R. Chim. 2004, 7, 611-616. [CrossRef]

6. USDA. World Agricultural Production. 2018. Available online: https://apps.fas.usda.gov/psdonline/circulars/ production.pdf (accessed on 11 May 2018). 
7. Bushong, J.A.; Griffith, A.P.; Peeper, T.F.; Epplin, F.M. Continuous winter wheat versus a winter canola-winter wheat rotation. Agron. J. 2012, 104, 324-330. [CrossRef]

8. Rathke, G.-W.; Christen, O.; Diepenbrock, W. Effects of nitrogen source and rate on productivity and quality of winter oilseed rape (Brassica napus L.) grown in different crop rotations. Field Crops Res. 2005, 94, 103-113. [CrossRef]

9. Sieling, K.; Kage, H. Efficient N management using winter oilseed rape. A review. Agron. Sustain. Dev. 2010, 30, 271-279. [CrossRef]

10. Zając, T.; Klimek-Kopyra, A.; Oleksy, A.; Lorenc-Kozik, A.; Ratajczak, K. Analysis of yield and plant traits of oilseed rape (Brassica napus L.) cultivated in temperate region in light of the possibilities of sowing in arid areas. Acta Agrobot. 2016, 69, 1-13. [CrossRef]

11. Swain, S.; Kay, P.; Ogawa, M. Preventing unwanted breakups: Using polygalacturonases to regulate cell separation. Plant Signal. Behav. 2011, 6, 93-97. [CrossRef]

12. Szot, B.; Szpryngiel, M.; Tys, J. Crop yield losses reduction at harvest, from research to adoption. In Encyclopedia of Agrophysics; Gliński, J., Horabik, J., Lipiec, J., Eds.; Springer: Dordrecht, The Netherlands, 2011; pp. 176-180.

13. Bennett, E.J.; Jeremy, A.R.; Wagstaff, C. The role of the pod in seed development: Strategies for manipulating yield. New Phytol. 2011, 190, 838-853. [CrossRef]

14. Hossain, S.; Kadkol, G.P.; Raman, R.; Salisbury, P.A.; Raman, H. Breeding Brassica napus for shatter resistance. In Plant Breeding; Abdurakhmonov, I., Ed.; InTech: Rijeka, Croatia, 2012; Chapter 14; pp. 313-332.

15. Diepenbrock, W. Yield analysis of winter oilseed rape (Brassica napus L.): A review. Field Crops Res. 2000, 67, 35-49. [CrossRef]

16. Meakin, P.J.; Roberts, J.A. Dehiscence of fruit in oilseed rape (Brassica napus L.): II. The role of cell wall degrading enzymes and ethylene. J. Exp. Bot. 1990, 41, 1003-1011. [CrossRef]

17. Roberts, J.A.; Elliott, K.A.; Gonzalez-Carranza, Z.H. Abscission, dehiscence, and other cell separation processes. Annu. Rev. Plant Biol. 2002, 53, 131-158. [CrossRef]

18. Gulden, R.H.; Shirtliffe, S.J.; Thomas, A.G. Harvest losses of canola (Brassica napus) cause large seedbank inputs. Weed Sci. 2003, 51, 83-86. [CrossRef]

19. Zhu, Y.M.; Li, Y.D.; Colbach, N.; Ma, K.P.; Wei, W.; Mi, X.C. Seed losses at harvest and seed persistence of oilseed rape (Brassica napus) in different cultural conditions in Chinese farming systems. Weed Res. 2012, 52, 317-327. [CrossRef]

20. Bruce, D.M.; Hobson, R.N.; Morgan, C.L.; Child, R.D. Threshability of shatter-resistant seed pods in oilseed rape. J. Agric. Eng. Res. 2001, 80, 343-350. [CrossRef]

21. Nunes, A.L.; Ascari, J.; Pereira, L.; Sossmeier, S.G.; Bispo, N.B. Pod sealant and canola harvest methods for pod shattering mitigation. Aust. J. Crop Sci. 2015, 9, 865-869.

22. Wang, R.; Ripley, V.L.; Rakow, G. Pod shatter resistance evaluation in cultivars and breeding lines of Brassica napus, B. juncea and Sinapis alba. Plant Breed. 2007, 126, 588-595. [CrossRef]

23. Haile, T.A.; Holzapfel, C.B.; Shirtliffe, S.J. Canola genotypes and harvest methods affect seedbank addition. Agron. J. 2014, 106, 236-242. [CrossRef]

24. Špokas, L.; Velička, R.; Marcinkevičienè, A.; Domeika, R. Optimization of spring rape harvest time by choosing crop varieties. Die Bodenkultur 2004, 55, 113-120. (in German).

25. Pahkala, K.; Sankari, H. Seed loss as a result of pod shatter in spring rape and spring turnip rape in Finland. Agric. Food Sci. Finl. 2001, 10, 209-216. [CrossRef]

26. Bruce, D.M.; Farrent, J.W.; Morgan, C.L.; Child, R.D. Determining the oilseed rape pod strength needed to reduce seed loss due to pod shatter. Biosyst. Eng. 2002, 81, 179-184. [CrossRef]

27. Kosteckas, R.; Liakas, V.; Šiuliauskas, A.; Rauckis, V.; Liakienè, E.; Jakienè, E. Effect of pinolene on winter rape seed losses in relation to maturity. Agron. Res. 2009, 7, 347-354.

28. Gulden, R.H.; Cavalieri, A.; Syrovy, L.D.; Shirtliffe, S.J. Pod drop in Brassica napus is linked to weight-adjusted pod-retention resistance. Field Crops Res. 2017, 205, 34-44. [CrossRef]

29. Morgan, C.L.; Bruce, D.M.; Child, R.; Ladbrooke, Z.L.; Arthur, A.E. Genetic variation for pod shatter resistance among lines of oilseed rape developed from synthetic B. napus. Field Crops Res. 1998, 58, 153-165. [CrossRef]

30. Gan, Y.; Malhi, S.S.; Brandt, S.A.; McDonald, C.L. Assessment of seed shattering resistance and yield loss in five oilseed crops. Can. J. Plant Sci. 2008, 88, 267-270. [CrossRef]

31. Cavalieri, A.; Lewis, D.W.; Gulden, R.H. Pod drop and pod shatter are not closely related in canola. Crop Sci. 2014, 54, 1184-1188. [CrossRef] 
32. Child, R.D.; Summers, J.E.; Babij, J.; Farrent, J.W.; Bruce, D.M. Increased resistance to pod shatter is associated with changes in the vascular structure in pods of a resynthesized Brassica napus line. J. Exp. Bot. 2003, 54, 1919-1930. [CrossRef]

33. Ma, N.; Zhang, C.L.; Li, J.; Zhang, M.H.; Cheng, Y.G.; Li, G.M.; Zhang, S. Mechanical harvesting effects on seed yield loss, quality traits and profitability of winter oilseed rape (Brassica napus L). J. Integr. Agric. 2012, 11, 1297-1304. [CrossRef]

34. Price, J.S.; Hobson, R.N.; Neale, M.A.; Bruce, D.M. Seed losses in commercial harvesting of oilseed rape. J. Agric. Eng. Res. 1996, 65, 183-191. [CrossRef]

35. Hobson, R.N.; Bruce, D.M. Seed loss when cutting a standing crop of oilseed rape with two types of combine harvester header. Biosyst. Eng. 2002, 81, 281-286. [CrossRef]

36. Špokas, L.; Steponavičius, D. Evaluating the effectiveness of pinolene based pod sealant for reducing shattering losses in several cultivars of rape (Brassica napus L.). Bulg. J. Agric. Sci. 2014, 20, 310-320.

37. Pits, N.; Kubacki, K.; Tys, J. Influence of application of plant growth regulators and desiccants on yield and quality of winter oilseed rape. Int. Agrophysics 2008, 22, 67-70.

38. Bauša, L.; Steponavičius, D.; Jotautienè, E.; Kemzūraitè, A.; Zaleckas, E. Application of rape pod sealants to reduce adverse environmental impacts. J. Sci. Food Agric. 2018, 9, 2428-2436. [CrossRef] [PubMed]

39. Darginavičienè, J.; Novickienè, L.; Gavelienè, V.; Jurkonienė, S.; Kazlauskienè, D. Ethephon and Aventrol as tools to enhance spring rape productivity. Cent. Eur. J. Biol. 2011, 6, 606-615. [CrossRef]

40. Mousavi-Avval, S.H.; Rafiee, Sh.; Sharifi, M.; Hosseinpour, S.; Notarnicola, B.; Tassielli, G.; Renzulli, P.A.; Khanali, M. Use of LCA indicators to assess Iranian rapeseed production systems with different residue management practices. Ecol. Indic. 2017, 80, 31-39. [CrossRef]

41. Sanz Requena, J.; Guimaraes, A.C.; Alpera, S.Q.; Gangas, E.R.; Hernandez-Navarro, S.; Gracia, L.N.; Cuesta, H.F. Life Cycle Assessment (LCA) of the biofuel production process from sunflower oil, rapeseed oil and soybean oil. Fuel Process. Technol. 2011, 92, 190-199. [CrossRef]

42. Forleo, M.B.; Palmieri, N.; Suardi, A.; Coaloa, D.; Pari, L. The eco-efficiency of rapeseed and sunflower cultivation in Italy. Joining environmental and economic assessment. J. Clean. Prod. 2018, 172, 3138-3153. [CrossRef]

43. Saarinen, M.; Virtanen, Y.; Hyvärinen, H. LCAs for a Large Repertoire of Finnish Outdoor Plant Products. In Proceedings of the 8th International Conference on Life Cycle Assessment on the Agrifood Sector, Saint-Malo, France, 1-4 October 2012; Corson, M.S., Van der Werf, H.M.G., Eds.; Book of Abstracts. pp. 811-812.

44. Naujokienè, V.; Šarauskis, E.; Bleizgys, R.; Sasnauskienè, J. Soil biotreatment effectiveness for reducing global warming potential from main polluting tillage operations in life cycle assessment phase. Sci. Total Environ. 2019, 671, 805-817. [CrossRef]

45. Cocco, D.; Deligios, P.; Ledda, L.; Sulas, L.; Virdis, A.; Carboni, G. LCA study of oleaginous bioenergy chains in a Mediterranean environment. Energies 2014, 7, 6258-6281. [CrossRef]

46. Fiorentino, G.; Ripa, M.; Mellino, S.; Fahd, S.; Ulgiati, S. Life cycle assessment of Brassica carinata biomass conversion to bioenergy and platform chemicals. J. Clean. Prod. 2014, 66, 174-187. [CrossRef]

47. Bieńkowski, J.F.; Dąbrowicz, R.; Holka, M.; Jankowiak, J. Carbon footprint of rapeseed in conventional farming: Case study of large-sized farms in Wielkopolska region (Poland). Asian J. Appl. Sci. Eng. 2015, 4, 191-200.

48. Iriarte, A.; Rieradevall, J.; Gabarrell, X. Life cycle assessment of sunflower and rapeseed as energy crops under Chilean conditions. J. Clean. Prod. 2010, 18, 336-345. [CrossRef]

49. Khanali, M.; Mousavi, S.A.; Sharifi, M.; Nasab, F.K.; Chau, K.-W. Life cycle assessment of canola edible oil production in Iran: A case study in Isfahan province. J. Clean. Prod. 2018, 196, 714-725. [CrossRef]

50. Stephenson, A.L.; Dennis, J.S.; Scott, S.A. Improving the sustainability of the production of biodiesel from oilseed rape in the UK. Process Saf. Environ. Prot. 2008, 86, 427-440. [CrossRef]

51. Queirós, J.; Malça, J.; Freire, F. Environmental life-cycle assessment of rapeseed produced in Central Europe: Addressing alternative fertilization and management practices. J. Clean. Prod. 2015, 99, 266-274. [CrossRef]

52. MacWilliam, S.; Sanscartier, D.; Lemke, R.; Wismer, M.; Baron, V. Environmental benefits of canola production in 2010 compared to 1990: A life cycle perspective. Agric. Sys. 2016, 145, 106-115. [CrossRef] 
53. Kazemi, H.; Hassanpour-Bourkheili, S.; Kamkar, B.; Soltani, A.; Gharanjic, K.; Nazari, N.M. Estimation of greenhouse gas (GHG) emission and energy use efficiency (EUE) analysis in rain fed canola production (case study: Golestan province, Iran). Energy 2016, 116, 694-700. [CrossRef]

54. Peter, C.; Helming, K.; Nendel, C. Do green house gas emission calculations from energy crop cultivation reflect actual agricultural management practices?-A review of carbon footprint calculators. Renew. Sust. Energy Rev. 2017, 67, 461-476. [CrossRef]

55. Kadkol, G.P.; Macmillan, R.H.; Burrow, R.P.; Halloran, G.M. Evaluation of Brassica genotypes for resistance to shatter. I. Development of a laboratory test. Euphytica 1984, 33, 63-73. [CrossRef]

56. Azadbakht, M.; Esmaeilzadeh, E.; Shahabi, A.H. Investigation the behavior of canola pods versus effect of impact and friction forces. J. Agric. Technol. 2013, 9, 1035-1044.

57. Kadkol, G.P. Brassica Shatter-Resistance Research Update. In Proceedings of the 16th Australian Research Assembly on Brassicas Conference, Ballarat, Australia, 14-16 September 2009; pp. 104-109.

58. Summers, J.E.; Bruce, D.M.; Vancanneyt, G.; Redig, P.; Werner, C.P.; Morgan, C.; Child, R.D. Pod shatter resistance in the resynthesized Brassica napus line DK142. J. Agric. Sci. 2003, 140, 43-52. [CrossRef]

59. Squires, T.M.; Gruwel, M.L.H.; Zhow, R.; Sokhansanj, S.; Abrams, S.R.; Cutler, A.J. Dehydration and dehiscence in siliques of Brassica napus and Brassica rapa. Can. J. Bot. 2003, 81, 248-254. [CrossRef]

60. Rudko, T. Attempt of application of bending test for evaluation of spring rapeseed pods cracking resistance. Acta Agrophysica 2000, 37, 193-198.

61. Goedkoop, M.; Oele, M.; Leijting, J.; Ponsioen, T.; Meijer, E. Introduction to LCA with SimaPro; PRé Consultants: Amersfoort, The Netherlands, 2013.

62. Goedkoop, M.; Oele, M.; Vieira, M.; Leijting, J.; Ponsioen, T.; Meijer, E. Simapro Tutorial; PRé Consultants: Amersfoort, The Netherlands, 2014.

63. Davies, G.C.; Bruce, D.M. Fracture mechanics of oilseed rape pods. J. Mater. Sci. 1997, 32, 5895-5899. [CrossRef]

64. Peng, P.; Li, Y.; Mei, D.; Liu, D.; Fu, L.; Wang, H.; Sang, S.; Chen, Y.; Hu, Q. Optimization and experiment of assessment method for pod shatter resistance in Brassica napus L. Trans. Chin. Soc. Agric. Eng. 2013, 29, 19-25.

65. Li, Y.; Zhu, J.; Xu, L.; Zhao, Z. Experiment on strength of rapeseed pod dehiscence based on impending fracturing method. Trans. Chin. Soc. Agric. Eng. 2012, 28, 111-115.

66. Morgan, C.L.; Ladbrooke, Z.L.; Bruce, D.M.; Child, R.; Arthur, A.E. Breeding oilseed rape for pod shattering resistance. J. Agric. Sci. 2000, 135, 347-359. [CrossRef]

67. Szot, B.; Tys, J.; Rudko, T. Estimation of the influence of nitrogen fertilization (ammonium nitrate or urea) on mechanical properties of rape siliques. Int. Agrophys. 1994, 8, 143-146.

68. Spence, J.; Vercher, Y.; Gates, P.; Harris, N. 'Pod shatter' in Arabidopsis thaliana, Brassica napus and B. juncea. J. Microsc. 1996, 181, 195-203. [CrossRef]

69. Holloway, P.J.; Ellis, M.B.; Webb, D.A.; Western, N.M.; Tuck, C.R.; Hayes, A.L.; Miller, P.C.H. Effects of some agricultural tank-mix adjuvants on the deposition efficiency of aqueous sprays on foliage. Crop Prot. 2000, 9, 27-37. [CrossRef]

70. Churaev, N.V.; Esipova, N.E.; Hill, R.M.; Sobolev, V.D.; Starov, V.M.; Zorin, Z.M. The superspreading effect of trisiloxane surfactant solutions. Langmuir 2001, 17, 1338-1348. [CrossRef]

71. Zhongyan, G.; Xiaolong, X.; Lijuan, H. Study on the function of surfactant in the application of pesticides. Mod. Agrochem. 2003, 2, 21-23.

72. Mousavi-Avval, S.H.; Rafiee, S.; Sharifi, M.; Hosseinpour, S.; Shah, A. Combined application of Life Cycle Assessment and Adaptive Neuro-Fuzzy Inference System for modeling energy and environmental emissions of oilseed production. Renew. Sustain. Energy Rev. 2017, 78, 807-820. [CrossRef]

(C) 2019 by the authors. Licensee MDPI, Basel, Switzerland. This article is an open access article distributed under the terms and conditions of the Creative Commons Attribution (CC BY) license (http://creativecommons.org/licenses/by/4.0/). 